\title{
PERANCANGAN SISTEM INFORMASI PENUNJANG KEPUTUSAN REKAM JEJAK PEMELIHARAAN SARANA OPERASIONAL BERBASIS WEB PADA BLUD PUSKESMAS KECAMATAN CENGKARENG
}

\author{
Sri Rahayu ${ }^{1}$, Handy Januar Permana ${ }^{2}$, Syahrul Mubarok ${ }^{* 3}$ \\ ${ }^{1}$ Program Studi Teknik Informatika Fakultas Sains dan Teknologi Universitas Raharja \\ ${ }^{2,3}$ Program Studi Sistem Informasi Fakultas Sains dan Teknologi Universitas Raharja \\ Email: ${ }^{1}$ sri.rahayu@ raharja.info,${ }^{2}$ handy.permana@ $\underline{\text { raharja.info }},{ }^{3}$ syahrul.mubarok@ raharja.info
}

\begin{abstract}
Abstrak
Rekam jejak pemeliharaan suatu barang atau sarana operasional merupakan suatu hal yang sangat penting di dalam suatu instansi perusahaan. Oleh karena itu dibutuhkan adanya suatu sistem yang terkomputerisasi yang dapat membuat laporan rekam jejak pemeliharaan lebih efektif dan efisien dan diimbangi dengan sumber daya manusia yang memadai. Namun dalam pelaksanaannya, pada BLUD Puskesmas Kecamatan Cengkareng belum memiliki sistem yang dapat mencakup seluruh kegiatan pemeliharaan sarana operasional. Dikarenakan dalam proses pencatatan dan pengolahan data pemeliharaan sarana operasional masih dikerjakan secara semi komputerisasi yang menggunakan Ms. Excel dan catatan dalam sebuah buku sebagai media yang digunakan dan tentunya masih besar kemungkinan terjadinya human error. Sehingga diperlukan perancangan sistem informasi rekam jejak pemeliharaan sarana operasional yang efektif dan efisien. Penelitian ini menggunakan metode analisa PIECES (Performance, Information/Data, Economy, Control, Efficiency, Service), elisitasi kebutuhan sistem, serta pemodelan sistem dengan menggunakan UML (Unified Modelling Language) untuk menggambarkan secara visualisasi, yang selanjutnya diimplementasikan dengan bahasa pemrograman Hypertext Preprocessor (PHP) dengan basis data MySQL sebagai database yang digunakan. Dengan adanya perancangan sistem informasi rekam jejak pemeliharaan sarana operasional, dapat mempermudah bagian pemeliharaan dalam menghasilkan laporan rekam jejak pemeliharaan suatu barang atau sarana yang akurat dengan waktu yang cepat, sehingga menciptakan kinerja yang efektif dan efisien, serta dapat menunjang di dalam melakukan perencanaan kedepannya.
\end{abstract}

Kata Kunci-Pemeliharaan, Sarana, Rekam Jejak

Abstract

The track record of maintaining an item or operational facility is a very important thing in a company agency. Therefore we need a computerized system that can make maintenance track record reports more effective and efficient and balanced with adequate human resources. However, in its implementation, the Cengkareng Sub-district BLUD has no system that can cover all operational facilities maintenance activities. Because in the process of recording and processing data maintenance of operational facilities is still done semi-computerized using Ms. Excel and notes in a book as the media used and of course there is still a large possibility of human error. So that it is necessary to design an effective and efficient track record maintenance system for operational facilities. This study uses the PIECES analysis method (Performance, Information / Data, Economy, Control, Efficiency, Service), system requirements elicitation, and system modeling using UML (Unified Modeling Language) to visualize, which is 
then implemented with the Hypertext Preprocessor programming language (PHP) with MySQL database as the database used. With the design of an information system track record of maintenance of operational facilities, it can facilitate the maintenance section in producing a track record of maintenance of an item or an accurate facility with a fast time, thus creating effective and efficient performance, and can support future planning.

\section{Keywords-Maintenance, Facilities, Track Record}

\section{PENDAHULUAN}

Teknologi informasi sangat dibutuhkan keberadaannya hampir disetiap aspek kehidupan, khususnya dunia kerja profesional. Dengan adanya perkembangan teknologi informasi, perusahaan sangat membutuhkan sistem terkomputerisasi yang dapat memudahkan dan juga meningkatkan kecepatan pekerjaan sehingga hasil yang dicapai lebih optimal dan lebih baik.

BLUD Puskesmas Kecamatan Cengkareng ialah instansi pemerintah yang bergerak di bidang pelayanan kesehatan, instansi tersebut masih menggunakan sistem manual yang harus mencatat data pelaporan hasil pemeliharaan sarana operasional. Penggunaan dengan sistem manual sangat menyulitkan dan juga menyita waktu yang cukup lama, khususnya pada bagian pemeliharaan. Hal tersebut dikarenakan untuk mendapatkan suatu informasi mengenai rekam jejak pemeliharaan suatu barang, diperlukan waktu untuk mencari data pemeliharaan tersebut. Dengan kurang maksimalnya suatu data pemeliharaan maka akan memperlambat suatu informasi yang dibutuhkan oleh penanggung jawab pemeliharaan. Pemeliharaan sarana operasional memegang peranan penting bagi proses perencanaan agar dapat menentukan pembelian barang sesuai dengan kebutuhan dan kondisi di lapangan.

Hal-hal tersebut dapat dihindarkan, dengan laporan pemeliharaan sarana operasional yang menggunakan sistem terkomputerisasi. Dengan adanya suatu sistem komputerisasi dalam menyajikan informasi pemeliharaan sarana operasional yang lengkap serta dapat mengakses data, informasi secara cepat dalam hal pengolahan data.

\section{METODE PENELITIAN}

\section{Metode Pengumpulan Data}

\section{Metode Observasi ( Observation Research)}

Observasi yang dilakukan dengan cara pengamatan langsung pada lokasi penelitian yaitu BLUD Puskesmas Kecamatan Cengkareng, dalam bidang pelayanan kesehatan. Untuk mendapatkan data yang diteliti, maka akan dilakukan analisa dan evaluasi terhadap masalah yang berkaitan dengan topik yang akan dibahas.

2. Metode Wawancara (Interview Research)

Untuk melengkapi hasil observasi, dilakukan metode wawancara atau tanya jawab untuk mendapatkan suatu data dan dilakukan juga tanya jawab secara lisan kepada stakeholder dengan pelaksana yang berhubungan langsung dengan sistem pemeliharaan sarana untuk memperoleh data informasi yang diperlukan bagian pemeliharaan pada BLUD Puskesmas Kecamatan Cengkareng berupa elisitasi. Elisitasi merupakan rancangan yang dibuat berdasarkan sistem yang baru yang diinginkan oleh pihak manajemen terkait dan disanggupi oleh penulis untuk dieksekusi setelah dilakukan metode wawancara telah didapat elisitasi dan dilakukan melalui tiga tahap yaitu tahap 1, tahap 2, tahap 3 dan final elisitasi. Metode ini digunakan untuk memperoleh data yang lebih mendetail saat melakukan pengamatan secara langsung.

3. Studi Pustaka ( Literature Research )

Selain melakukan observasi dan wawancara dilakukan juga pencarian data dengan cara studi pustaka. Dalam metode ini menggunakan sumber dari : buku-buku, jurnal dan penelitian sebelumnya yang berkaitan dengan judul penelitian Skripsi yang diambil. 
Sehingga didapatkan gambaran secara teoritis yang berguna untuk membantu penganalisaan dan perancangan maupun penulisan penelitian ini.

\section{Metode Analisa Sistem}

Pada penelitian ini penulis menggunakan metode analisa PIECES ( Performance, Information, Economics, Control, Efficiency, Services ) untuk mengidentifikasi masalah history maintenance pada BLUD Puskesmas Kecamatan Cengkareng. Dari analisis ini akan diperoleh beberapa hal yang dari situ akan dapat disimpulkan masalah utama yang dihadapi secara jelas dan spesifik. Dan dari hasil analisis tersebut akan dapat dirumuskan berbagai usulan untuk membantu perancangan sistem yang lebih baik.

\section{LANDASAN TEORI}

\section{Konsep Dasar Sistem}

Menurut Jeperson Hutapean (2015 : 2-3), "Sistem adalah suatu jaringan kerja dari prosedur - prosedur yang saling berhubungan, berkumpul bersama - sama untuk melakukan kegiatan atau untuk melakukan sasaran tertentu".

\section{Konsep Dasar Informasi}

Menurut Raymond Mc. Leod di dalam buku Muhamad Muslihudin dan Oktafianto (2016 : 9), bahwa informasi adalah data yang telah diolah menjadi bentuk yang memiliki arti bagi si penerima dan bermanfaat bagi pengambilan keputusan saat ini atau mendatang.

Menurut Muhamad Muslihudin dan Oktafianto (2016 : 9) Informasi merupakan data yang diolah menjadi bentuk yang berguna untuk membuat keputusan.

\section{Konsep Dasar Sistem Informasi}

Menurut Aris Wijayanti dkk Vol. 2 No. 1 (2017) "Sistem informasi adalah suatu pengumpulan data yang terorganisasi beserta tata cara penggunaanya yang mencakup lebih jauh daripada sekedar penyajian.

\section{Konsep Dasar Perancangan Sistem}

Menurut Suriaman Gulo dkk Vol. 2 No. 1 (2018), Perancangan sistem secara umum adalah untuk memberikan gambaran secara umum kepada admin tentang sistem yang baru.

\section{Konsep Dasar UML ( Unified Modeling Language)}

Menurut Asep Abdul Sofyan dkk Vol. 4 No. 1 (2014),UML disebut juga contoh bahasa yang terdiri dari banyak cara dan kaidah-kaidah yang sangat penting dalam perancangan dan desain suatu sistem, UML sebagai grafis utama untuk catatan cara mendesain dengan cepat dan prosedural.

\section{Konsep Dasar Elisitasi}

Definisi elisistasi menurut Ariawan dan Wahyuni dalam Jurnal Sisfotek Global (2015:63) adalah "Rancangan yang di buat berdasarkan sistem yang baru yang diinginkan oleh pihak manajemen terkait dan disanggupi oleh penulis untuk di eksekusi".

Menurut Sofa Sofiana Vol. 2 No. 1 (2017), Elisitasi merupakan rancangan yang dibuat berdasarkan sistem baru yang diinginkan oleh pihak manajemen terkait dan disanggupi oleh penulis untuk dieksekusi.

\section{Konsep Dasar Literature Review}

Menurut Rika Henda Safitri (2017:1041), "Studi literature adalah mencari referensi teori yang relevan dengan kasus atau permasalahan yang ditemukan. Referensi tersebut dapat di temukan di buku, jurnal, artikel laporan penelitian, dan situs - situs di internet."

Menurut Akhmad Sugianto (2017:23), "Metode literature adalah kajian yang dibaca oleh penulis dari berbagai referensi yang relevan dengan judul penulisan ini misalnya buku, ebook, jurnal \& makalah.”

\section{HASIL DAN PEMBAHASAN}

\section{Prosedur Sistem Yang Berjalan}

Prosedur perbaikan sarana operasional :

1) User membuat laporan kerusakan yang ditujukan ke bagian tata usaha. 
2) Bagian tata usaha menerima laporan kerusakan.

3) Bagian tata usaha membuat disposisi surat ke bagian pemeliharaan agar dilakukan perbaikan pada unit yang bersangkutan.

4) Petugas pemeliharaan melakukan peninjauan ke unit yang bersangkutan.

5) Petugas pemeliharaan melakukan analisa kerusakan yang terjadi.

6) Petugas melakukan perbaikan terhadap sarana operasional yang mengalami kerusakan.

7) Jika sarana operasional tersebut tidak bisa diperbaiki, maka petugas pemeliharaan akan melakukan penggantian spare part sesuai dengan stock yang tersedia.

8) Jika spare part yang dibutuhkan tidak tersedia maka petugas pemeliharaan akan membuat surat permohonan pembelian ke bagian pengadaan.

9) Petugas pemeliharaan membuat berita acara pemeliharaan.

\section{Use Case Diagram Sistem Yang Berjalan}

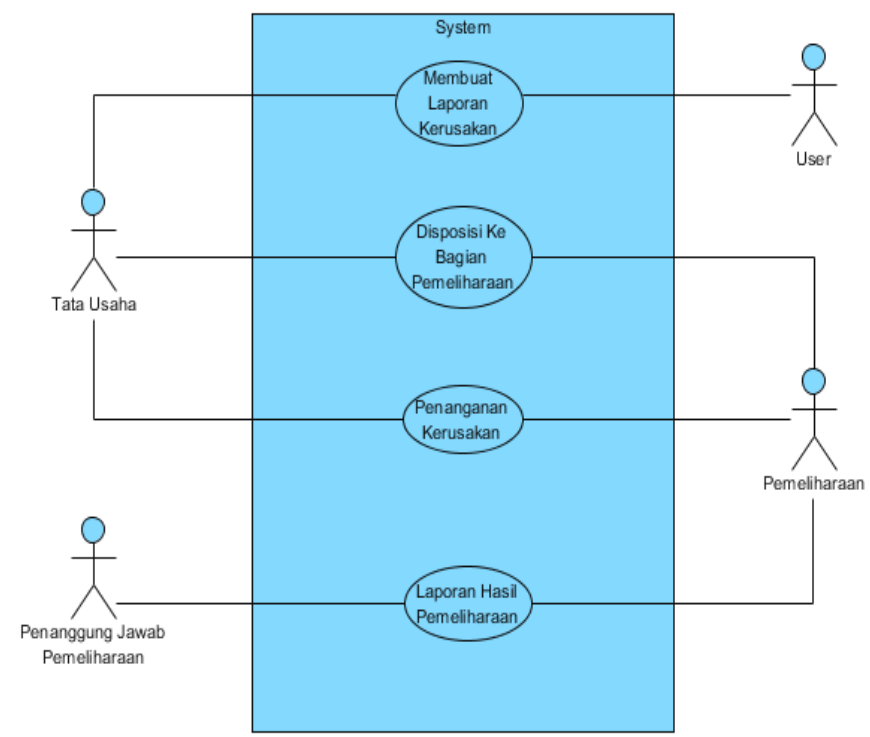

Gambar 1. Usecase Diagram Sistem yang Berjalan

Berdasarkan gambar 1. Use Case Diagram diatas terdapat:

a. Terdapat sebuah sistem yang mencakup kegiatan yang sedang berjalan

b. Empat aktor yang melakukan kegiatan, yaitu User, Tata Usaha, Pemeliharaan dan Penanggung Jawab Pemeliharaan. User melaporkan kerusakan ke bagian tata usaha, kemudian tata usaha mendisposisikan surat ke bagian pemeliharaan, pemeliharaan melakukan penanganan kerusakan dan membuat laporan hasil pemeliharaan ke penanggung jawab pemeliharaan.

c. Terdapat 4 use case diagram yang dilakukan oleh 4 aktor, yaitu : membuat laporan kerusakan, disposisi ke bagian pemeliharaan, penanganan kerusakan dan laporan hasil pemeliharaan. 


\section{Use Case Diagram Yang Diusulkan}

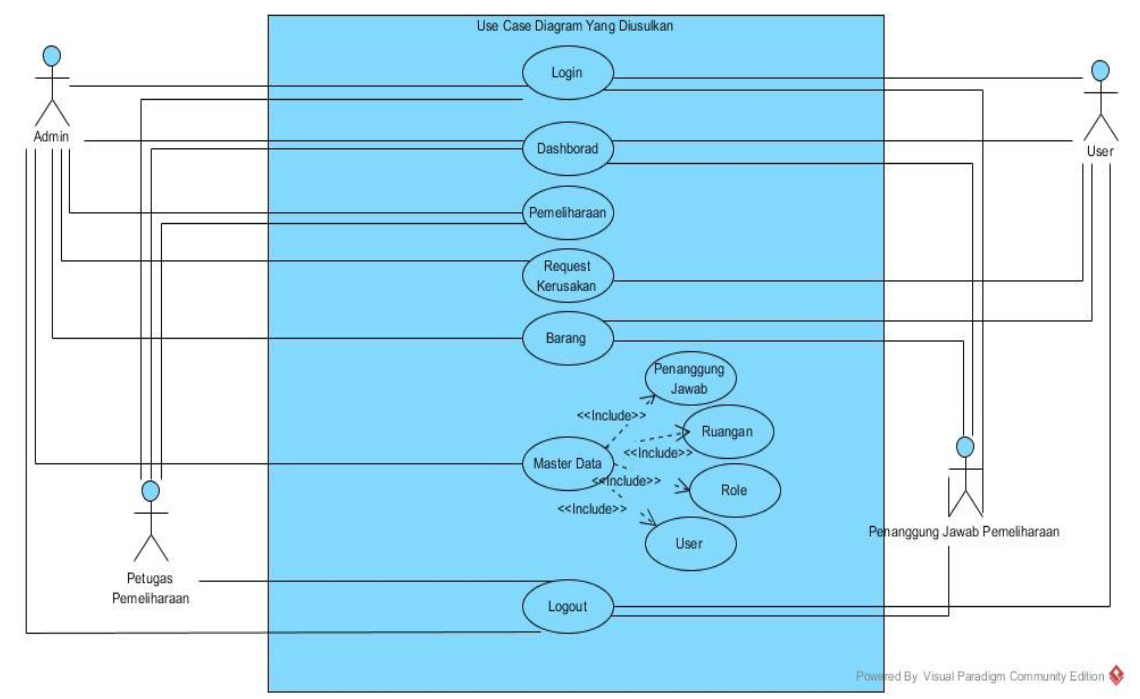

Gambar 2. Use Case Diagram Yang Diusulkan

Berdasarkan Gambar 2. diatas dapat dijelaskan sebagai berikut :

a. 1 (satu) sistem yang merupakan rancangan usulan sistem rekam jejak pemeliharaan sarana operasional.

b. 4 (empat) actor dalam kegiatan yaitu : admin, user, petugas pemeliharaan, penaggung jawab pemeliharaan.

c. 12 (dua belas) Use Case yang digunakan oleh actoryaitu :login, menampilkan dashboard, menampilkan menu pemeliharaan, menampilkan menu request kerusakan, menampilkan menu barang, menampilkan menu master data,menu, penanggung jawab, ruangan, role dan user.

d. 5 (lima) include yang menjelaskan bahwa Use Case berasal dari sumber secara eksplisit pada Use Case sebelumnya.

\section{Activity Diagram}

Berikut merupakan activity diagram yang menggambarkan alur aktivitas sistem rekam jejak pemeliharaan saran operasional yang sedang berjalan pada BLUD Puskesmas Kecamatan Cengkareng :

\section{Activity Diagram Sistem Yang Berjalan}

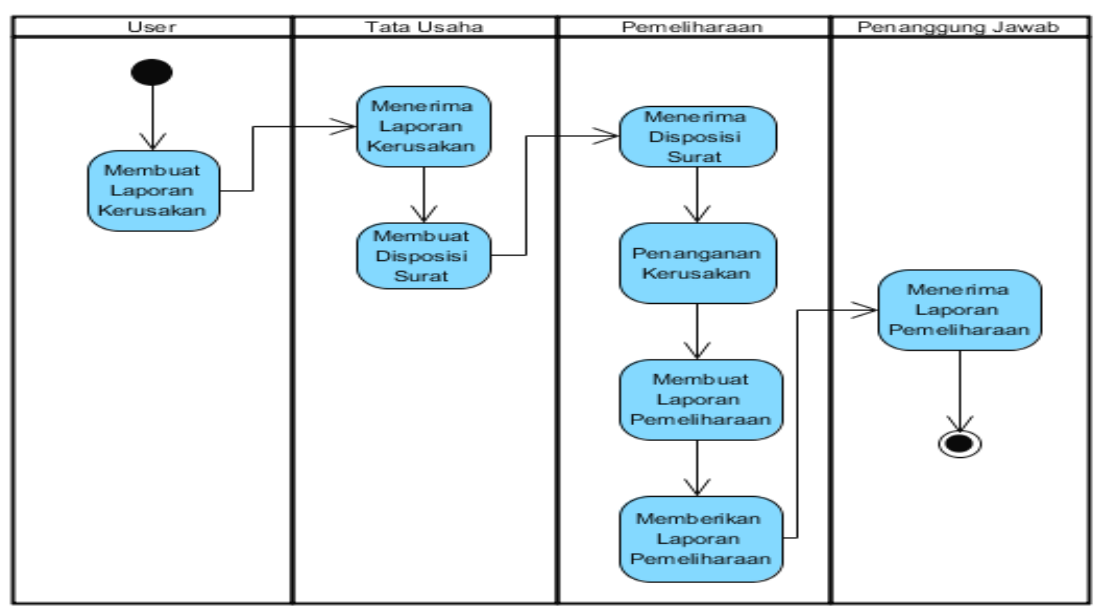

Gambar 3. Activity Diagram Sistem Yang Berjalan 
Berdasarkan gambar 3.activity diagram diatas terdapat :

a. $\quad$ Memiliki 1 buah initial node sebagai start point dikolom user.

b. Memiliki 8 buah action sebagai proses berjalan, yang terdiri dari : membuat laporan kerusakan, menerima laporan kerusakan, membuat disposisi surat, menerima disposisi surat, penanganan kerusakan, membuat laporan pemeliharaan, memberikan laporan pemeliharaan dan menerima laporan pemeliharaan.

c. $\quad$ Memiliki 1 buah final node sebagai end point dikolom pimpinan.

\section{Activity Diagram Yang Diusulkan}

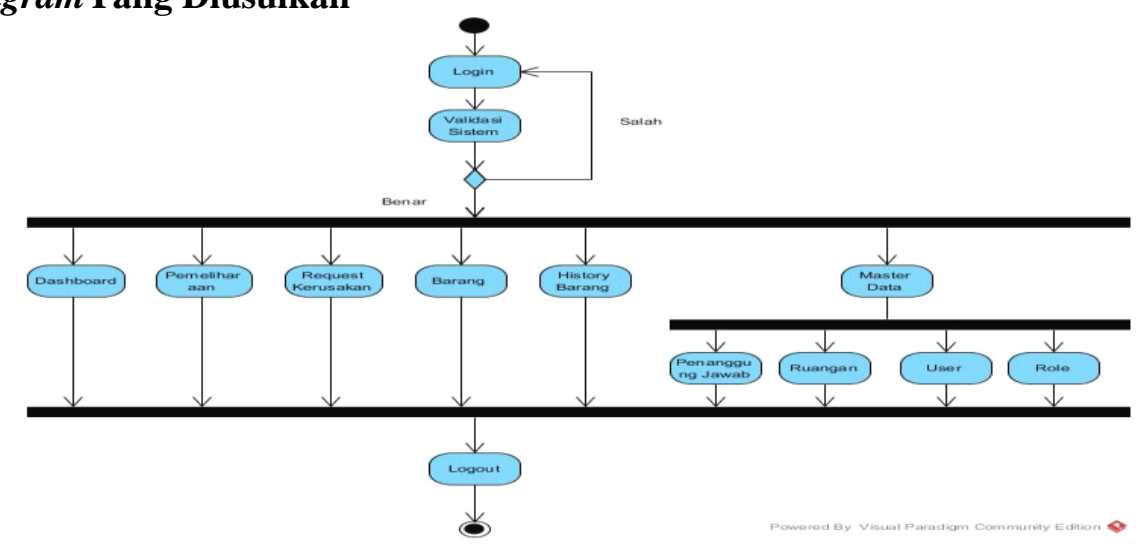

Gambar 4. Activity Diagram yang Diusulkan

Berdasarkan gambar 4.activity diagram yang diusulkan terdapat:

a. 1 (satu) initial node sebagai objek yang di awali.

b. 12 (dua belas) action state yang terdiri dari :login, validasi sistem, jika gagal kembali ke login, dashboard, pemeliharaan, request kerusakan, barang, master data yang terdiri dari 5 sub menu yaitu : sub menu menu, sub menu penanggung jawab, sub menu ruangan, sub menu user, sub menu role dan logout.

c. Terdapat 3 (tiga) fork node.

d. 1 (satu) final node menjelaskan bahwa alur sistem berakhir.

\section{Sequence Diagram}

Sequance diagram sistem yang berjalan saat ini pada BLUD Puskesmas Kecamatan Cengkareng dengan menunjukan hubungan antara user dengan komponen sistem yang berjalan dan umpan balik pada aktifitas transaksi integrasi komunikasi data kinerja.

\section{Sequence Diagram Sistem Yang Berjalan}

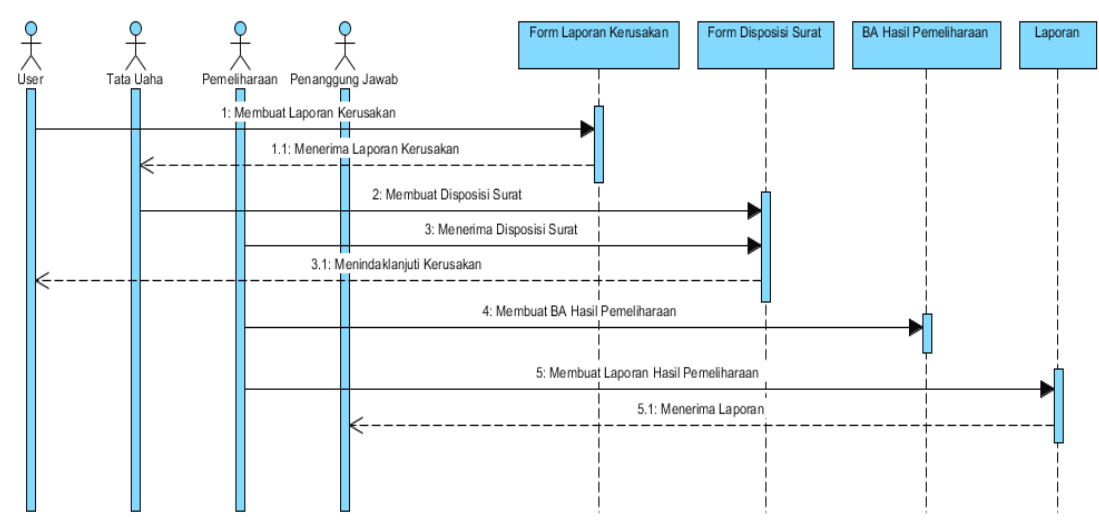

Gambar 5. Sequence Diagram yang Berjalan 
Berdasarkan gambar 5.terdapat :

1. Terdapat 4 aktor yang memiliki kegiatan diantaranya : User, Tata Usaha, Pemeliharaan dan Penanggung Jawab.

2. Terdapat 4 objek yang saling berinteraksi yaitu : Form Laporan Kerusakan, Form Disposisi Surat, BA Hasil Pemeliharaan dan Laporan.

\section{Analisa Sistem yang berjalan pada Sequence Diagram}

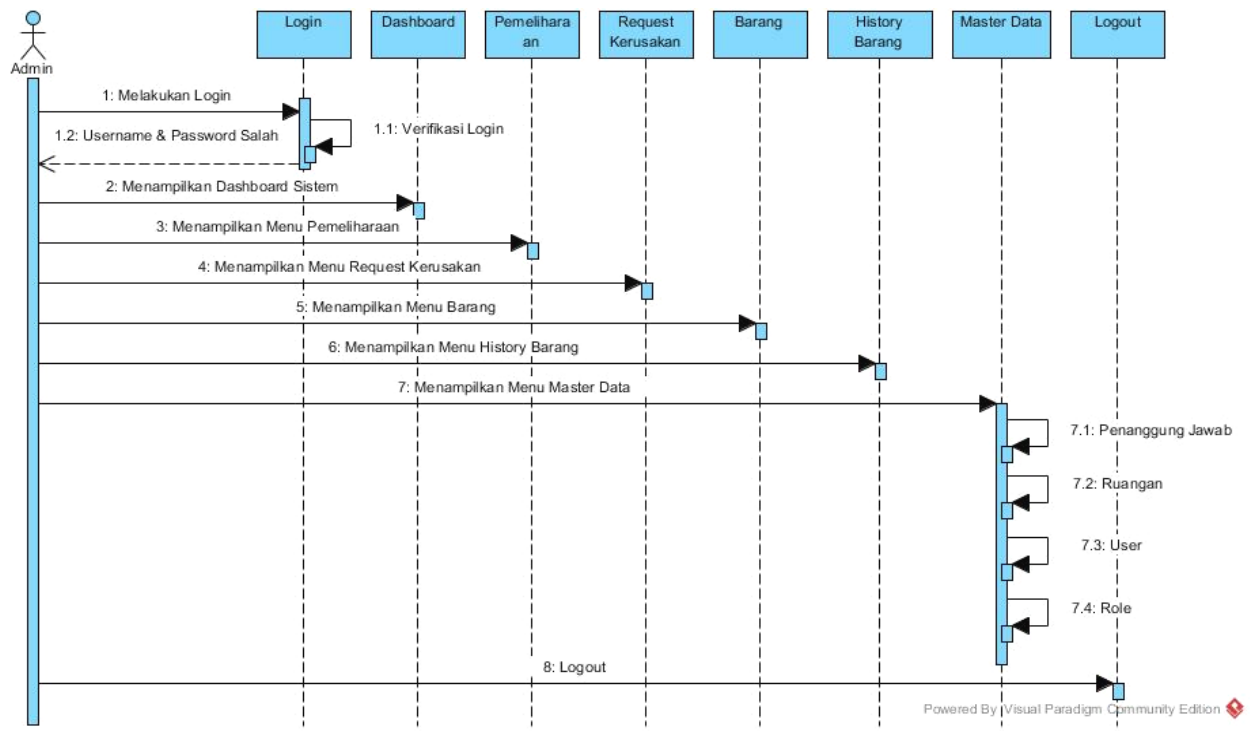

Gambar 6. Sequence Diagram yang Diusulkan

Berdasarkan gambar 6.Sequence Diagram Sistem Yang Diusulkan terdapat:

a. 4 (empat) actor yang melakukan kegiatan, yaitu Kepala Gudang, Staff Gudang, Admin, Purchasing

b. 6 (enam) Lifeline yaitu login, home, master, data, layout, laporan dan logout.

c. 10 (sepuluh) Message yang dilakukan actor

\section{Perbedaan Prosedur Sistem Berjalan dan Sistem Usulan}

Tabel 1. Perbedaan Sistem yang Berjalan dan Sistem Usulan

\begin{tabular}{|c|l|l|}
\hline No & \multicolumn{1}{|c|}{ Sistem Yang Berjalan } & \multicolumn{1}{c|}{ Sistem Yang Diusulkan } \\
\hline 1 & $\begin{array}{l}\text { Penanganan laporan masih manual } \\
\text { sehingga masih terjadi kehilangan } \\
\text { laporan. }\end{array}$ & $\begin{array}{l}\text { Terdapat filter laporan kerusakan } \\
\text { yang belum di tindak lanjuti dan } \\
\text { sudah di tindak lanjuti. }\end{array}$ \\
\hline 2 & $\begin{array}{l}\text { Data- data hasil pemeliharaan yang } \\
\text { masih disimpan dalam bentuk arsip, } \\
\text { sehingga berpotensi besar terhadap } \\
\text { kerusakan dan kehilangan data. }\end{array}$ & $\begin{array}{l}\text { Data sudah tersimpan di dalam } \\
\text { suatu database sehingga bisa dilihat } \\
\text { kapanpun dan darimanapun. }\end{array}$ \\
\hline 3 & $\begin{array}{l}\text { Data informasi tentang kondisi } \\
\text { sarana operasional masih kurang } \\
\text { relevan dikarenakan belum } \\
\text { dilakukan update data setelah } \\
\text { dilakukan pemeliharaan. }\end{array}$ & $\begin{array}{l}\text { Data kondisi barang selalu di } \\
\text { update apabila telah dilakukan } \\
\text { pemeliharan/perbaikan. }\end{array}$ \\
\hline 4 & $\begin{array}{l}\text { Biaya yang dibutuhkan cukup besar } \\
\text { untuk membeli kertas dan alat tulis }\end{array}$ & $\begin{array}{l}\text { Dengan adanya sistem ini dapat } \\
\text { menekan biaya pembelian alat tulis }\end{array}$ \\
\hline
\end{tabular}




\begin{tabular}{|c|c|c|}
\hline & dalam jangka panjang. & $\begin{array}{l}\text { kantor sehingga bisa mengurangi } \\
\text { biaya operasional. }\end{array}$ \\
\hline 5 & $\begin{array}{l}\text { Tidak adanya proteksi terhadap } \\
\text { data karena semua data disimpan } \\
\text { dalam bentuk arsip serta } \\
\text { pembatasan hak akses yang } \\
\text { mengakibatkan pihak yang tidak } \\
\text { terkait dapat mengakses data } \\
\text { tersebut yang menyebabkan } \\
\text { terjadinya kerusakan atau } \\
\text { kehilangan data. }\end{array}$ & $\begin{array}{l}\text { Data disimpan di dalam suatu } \\
\text { aplikasi sistem yang membutuhkan } \\
\text { autentikasi pada saat ini masuk ke } \\
\text { sistem tersebut sehingga bisa } \\
\text { meminimalisir hal-hal yang tidak } \\
\text { diinginkan. }\end{array}$ \\
\hline 6 & $\begin{array}{l}\text { Masih membutuhkan waktu lama } \\
\text { dalam proses pembuatan laporan } \\
\text { kondisi barang dikarenakan kondisi } \\
\text { yang tidak selalu update. }\end{array}$ & $\begin{array}{l}\text { Dengan adanya sistem terdapat } \\
\text { menu cetak laporan kondisi barang } \\
\text { dengan kondisi yang real time. }\end{array}$ \\
\hline 7 & $\begin{array}{l}\text { Membutuhkan waktu yang cukup } \\
\text { lama untuk melakukan pencarian } \\
\text { data. }\end{array}$ & $\begin{array}{l}\text { Terdapat menu kolom pencarian } \\
\text { dengan beberaapa kondisi sehingga } \\
\text { memudahkan dalam melakuka } \\
\text { pencarian data. }\end{array}$ \\
\hline 8 & $\begin{array}{l}\text { Sistem yang berjalan saat ini masih } \\
\text { mengalami banyak kekurangan } \\
\text { terutama dari sisi penyampaian } \\
\text { laporan yang membutuhkan waktu } \\
\text { yang cukup lama. }\end{array}$ & $\begin{array}{l}\text { Penyampaian laporan dapat } \\
\text { dilakukan kapanpun, dimanapun } \\
\text { karena kondisi yang selalu di } \\
\text { update. }\end{array}$ \\
\hline
\end{tabular}

\section{TAMPILAN SISTEM YANG DIUSULKAN}

\section{Tampilan Halaman Login}

\section{Keterangan :}

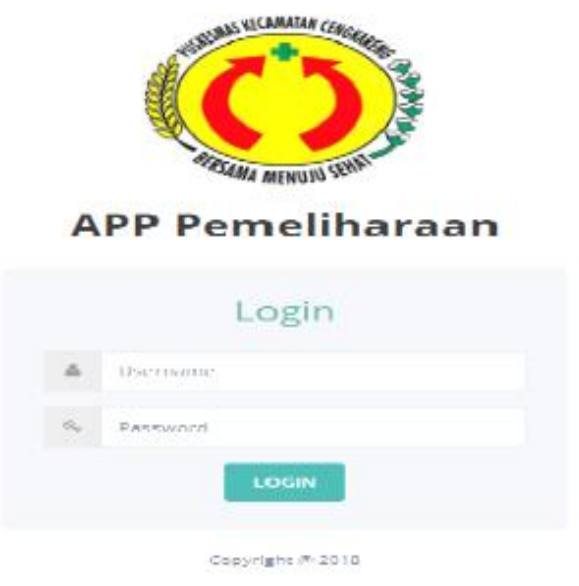

Gambar 7. Halaman Login

Tampilan halaman login merupakan tampilan awal ketika user atau admin menjalankan sistem ini. Pada halaman ini user atau admin diminta untuk memasukan username dan password. 


\section{Tampilan Halaman Dashboard}

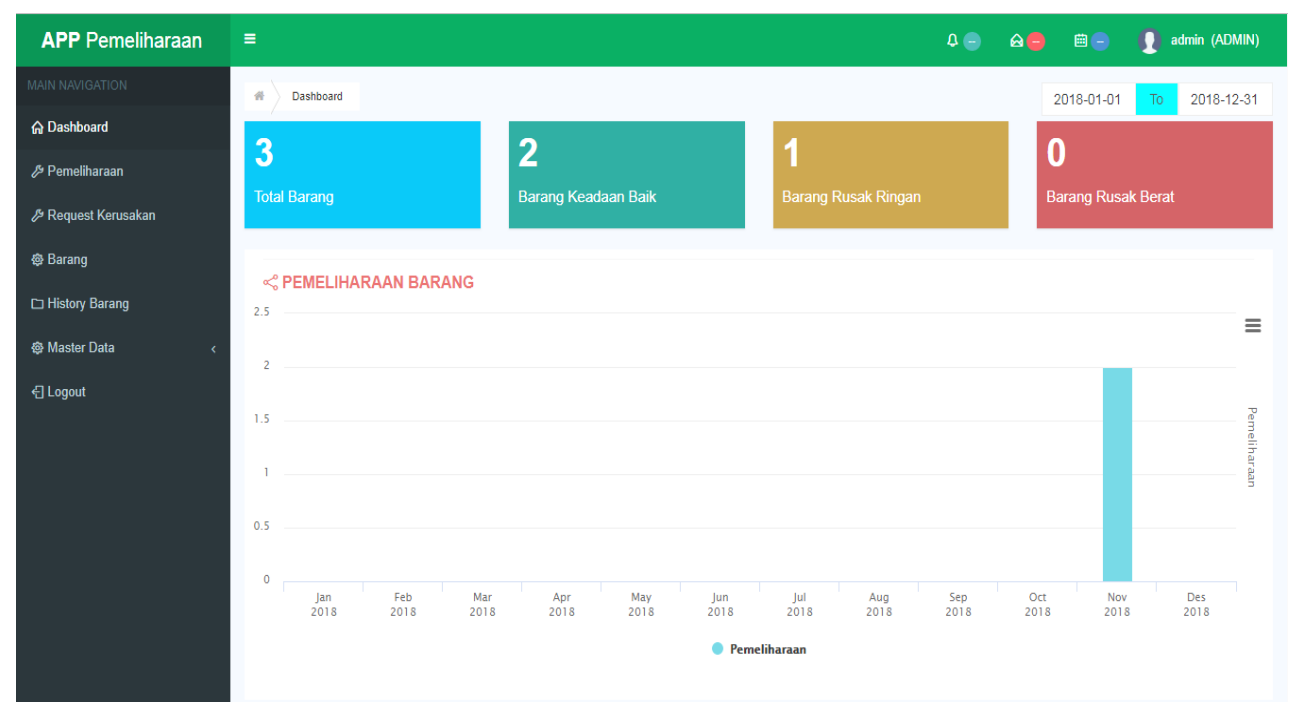

Gambar 8. Halaman Dashboard Admin

\section{Keterangan :}

Tampilan halaman dashboard admin ini muncul ketika admin telah melakukan login. Dalam halaman ini terdapat beberapa menu diantaranya dashboard, pemeliharaan, request kerusakan, barang dan login serta informasi kondisi barang dan informasi dalam bentuk grafik.

\section{Tampilan Sub Menu Role}

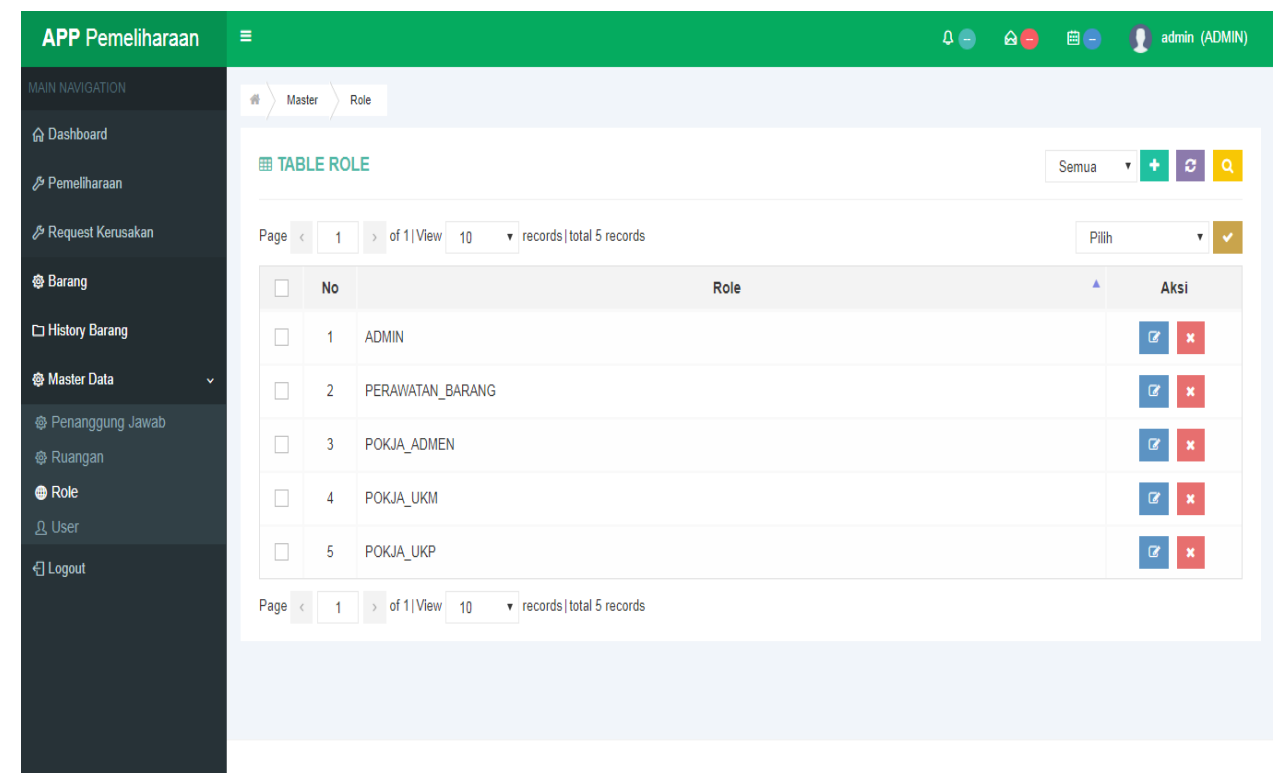

Gambar 9. Halaman Sub Menu Role

\section{Keterangan :}

Pada menu ini admin dapat mengatur hak akses bagi user dan petugas pemeliharaan untuk menghindari hal - hal yang tidak diinginkan. 


\section{Tampilan Sub Menu User}

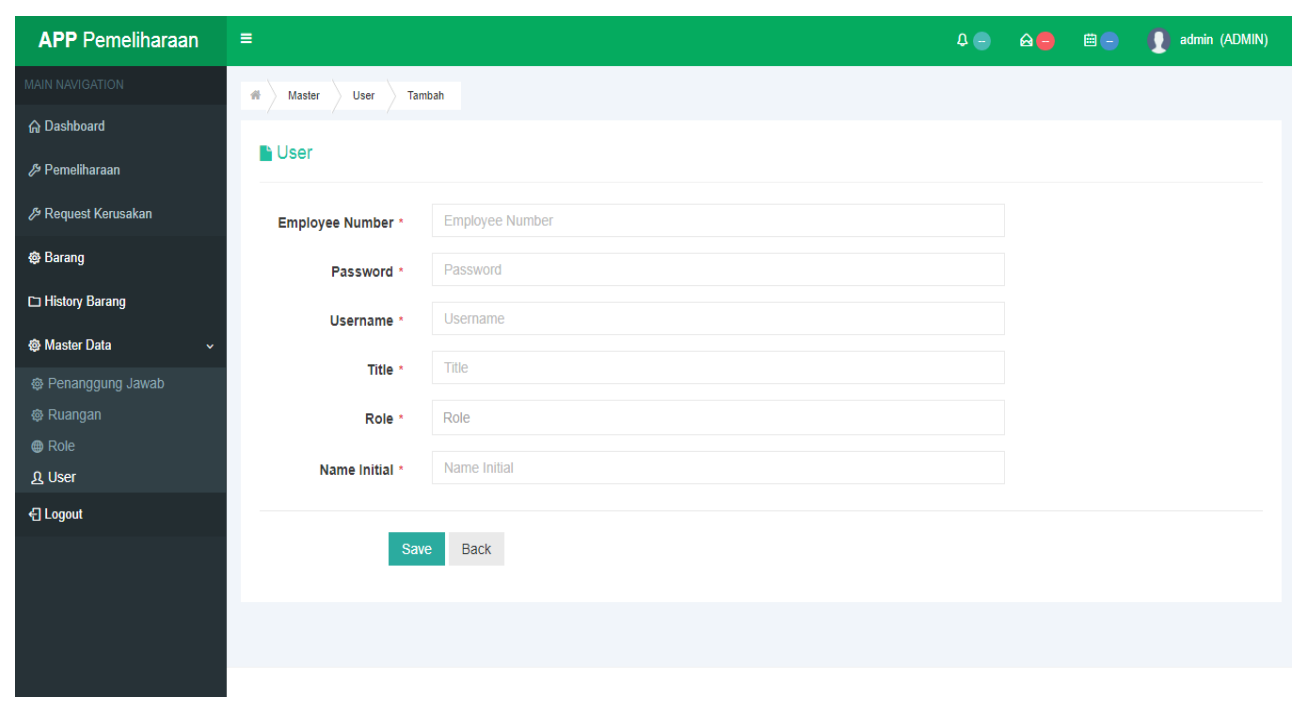

Gambar 10. Halaman Sub Menu User

\section{Keterangan :}

Pada menu ini terdapat button yang dapat melakukan tambah data user, edit data, hapus data dan cari data serta dapat menampilkan user yang sudah terdaftar sebelumnya.

\section{Tampilan Sub Menu Ruangan}

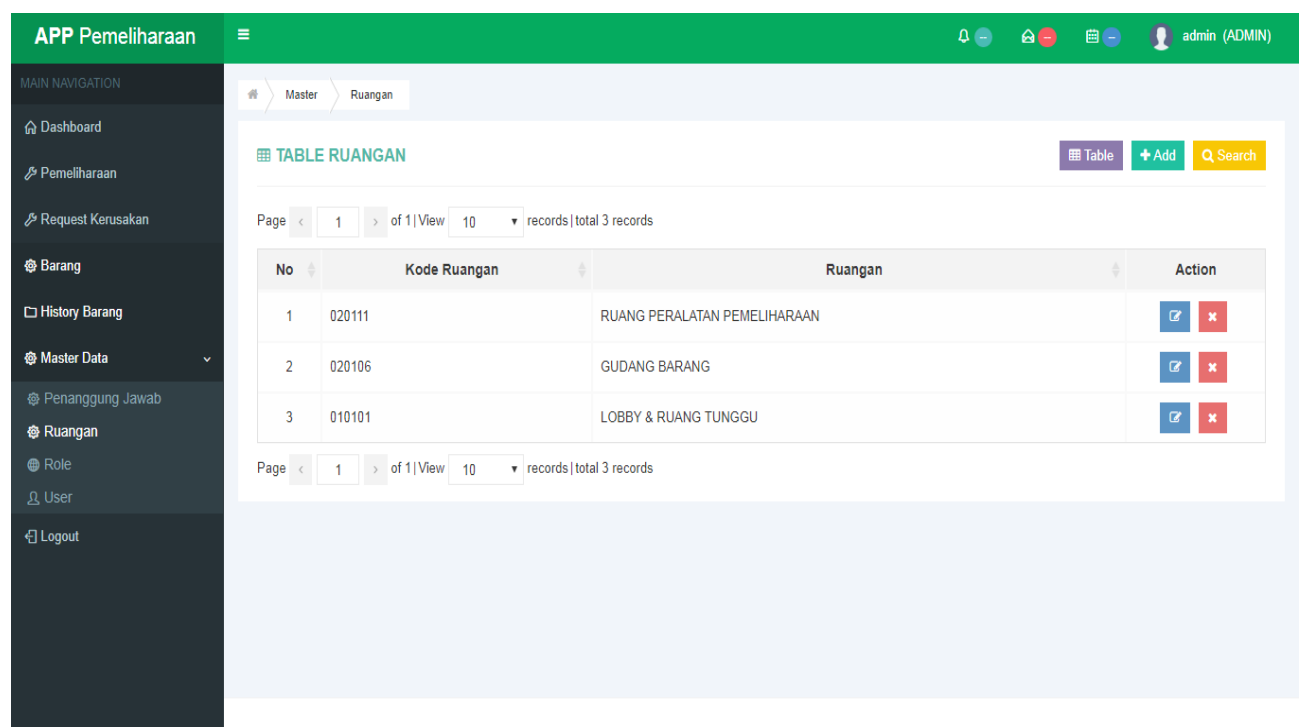

\section{Keterangan :}

Gambar 11. Halaman Sub Menu Ruangan

Pada menu ini menampilkan data ruangan yang telah ada serta dapat melakukan penambahan ruangan, edit ruangan, hapus ruangan dan cari ruangan. 


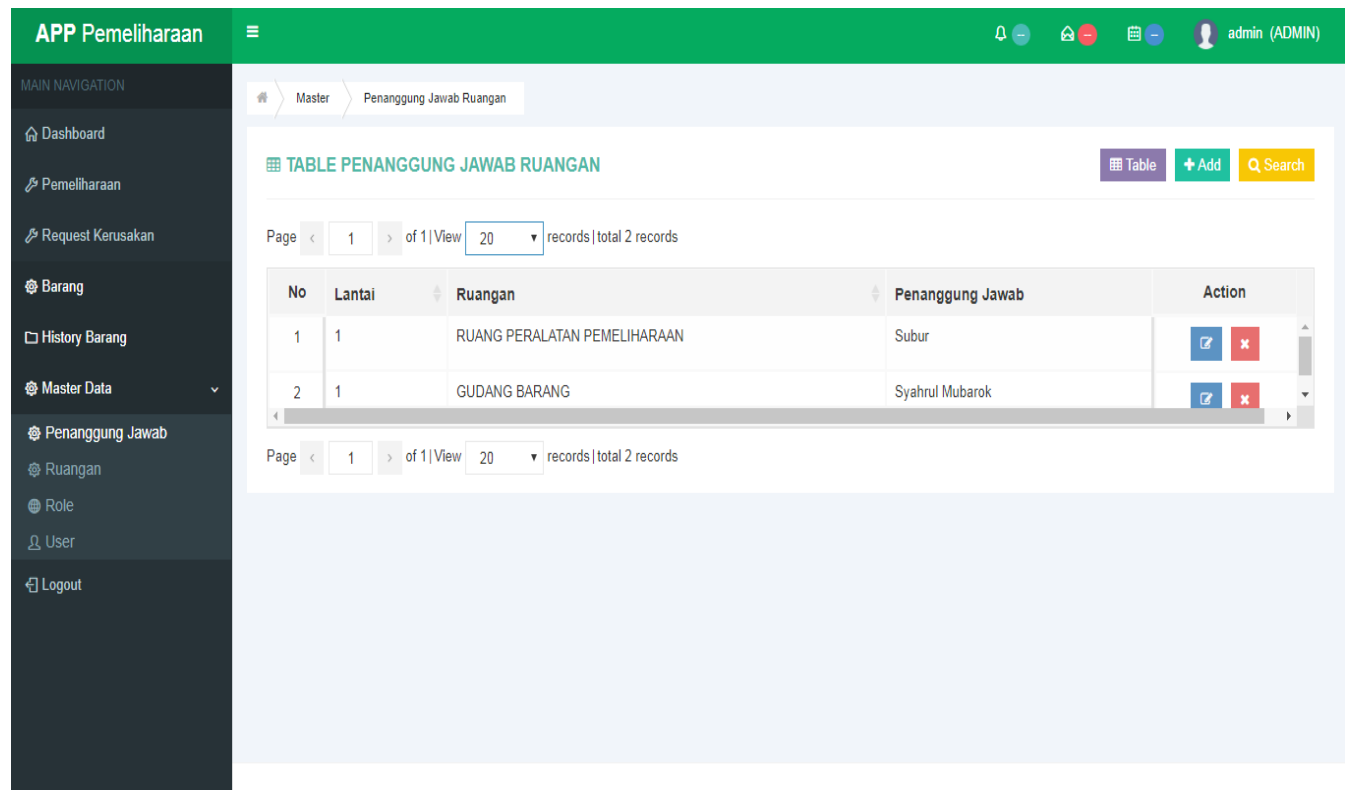

Gambar 12. Halaman Sub Menu Penanggung Jawab

\section{Keterangan :}

Pada menu ini menampilkan nama penanggung jawab setiap ruangan yang ada serta terdapat button yang berfungsi untuk melakukan tambah data, edit data, hapus data dan cari data.

\section{Tampilan Menu Request Kerusakan}

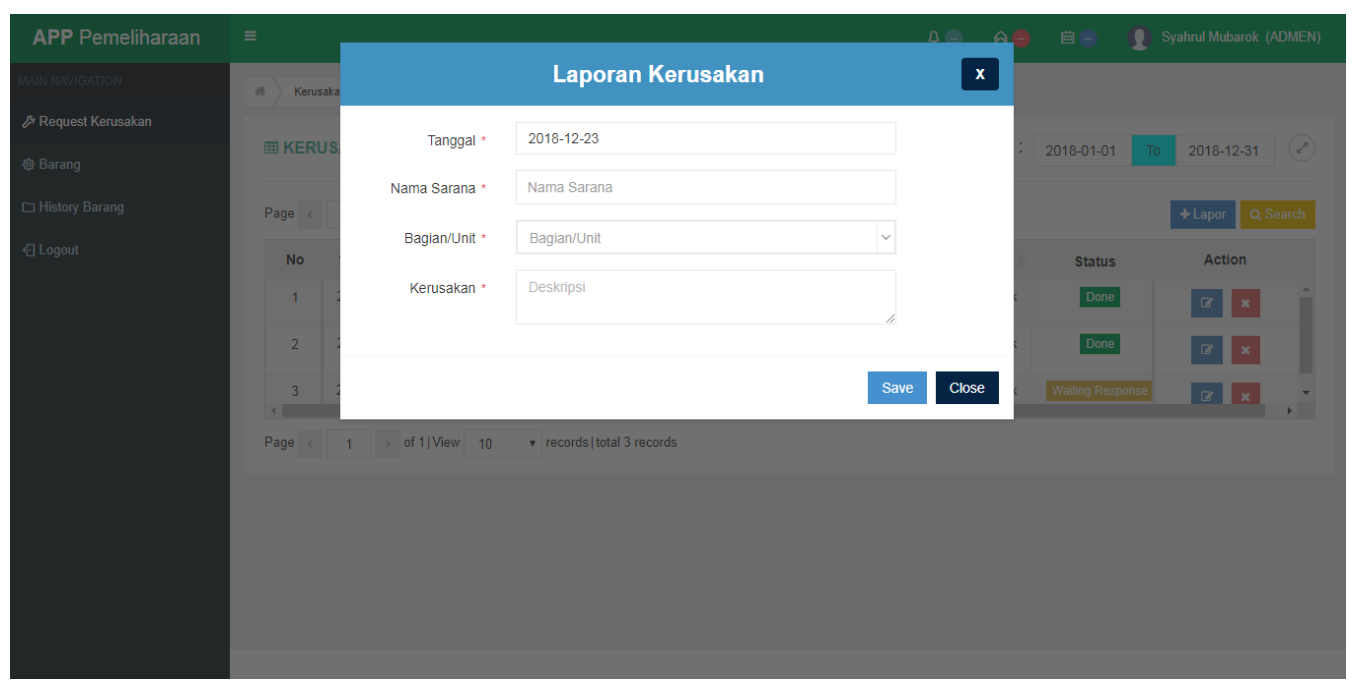

Gambar 13. Halaman Request Kerusakan

\section{Keterangan :}

Pada menu ini user bisa mengajukan request kerusakan dengan mengisi pada kolom text field tanggal, nama sarana, bagian/unit dan jenis kerusakan setelah itu di save. Apabila sudah mengajukan request maka akan muncul status waiting response. 


\section{Tampilan Menu Barang}

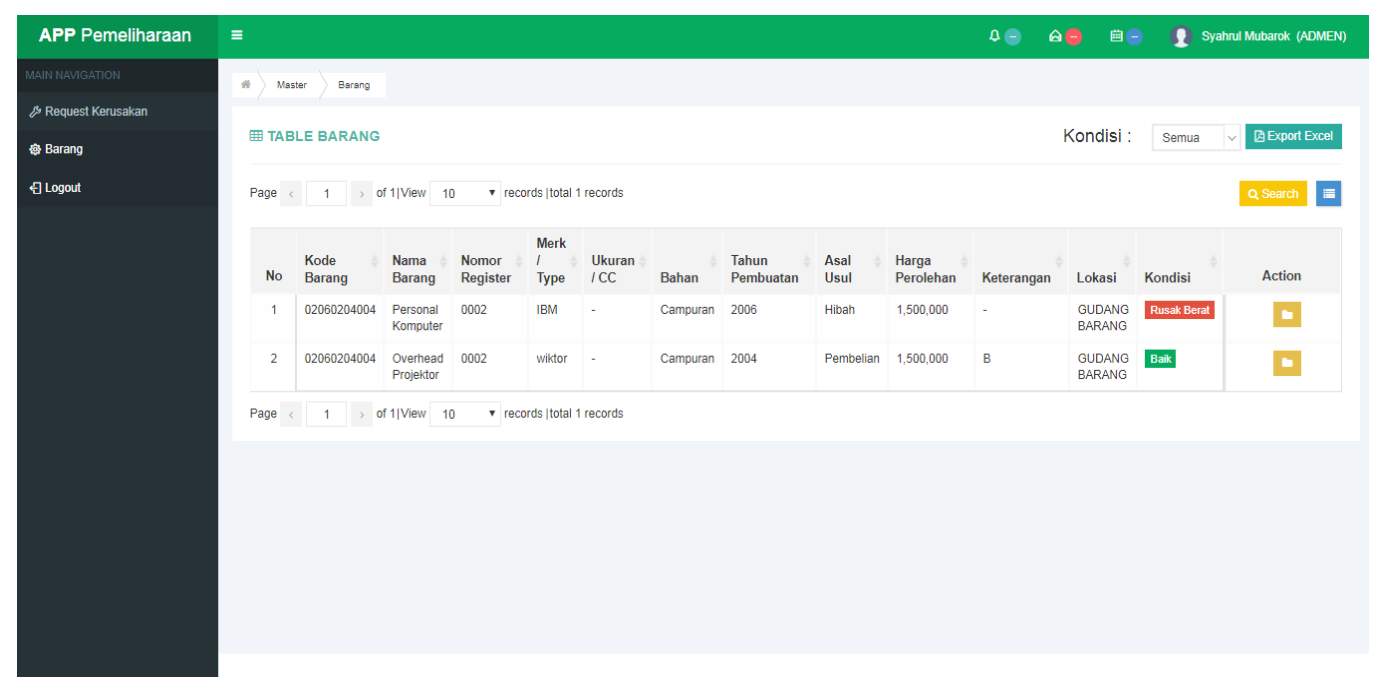

Gambar 14. Halaman Menu Barang

\section{Keterangan :}

Pada menu ini menampilkan daftar barang yang ada pada unit / bagian tersebut dengan semua kondisi.

\section{Tampilan Laporan History Barang}

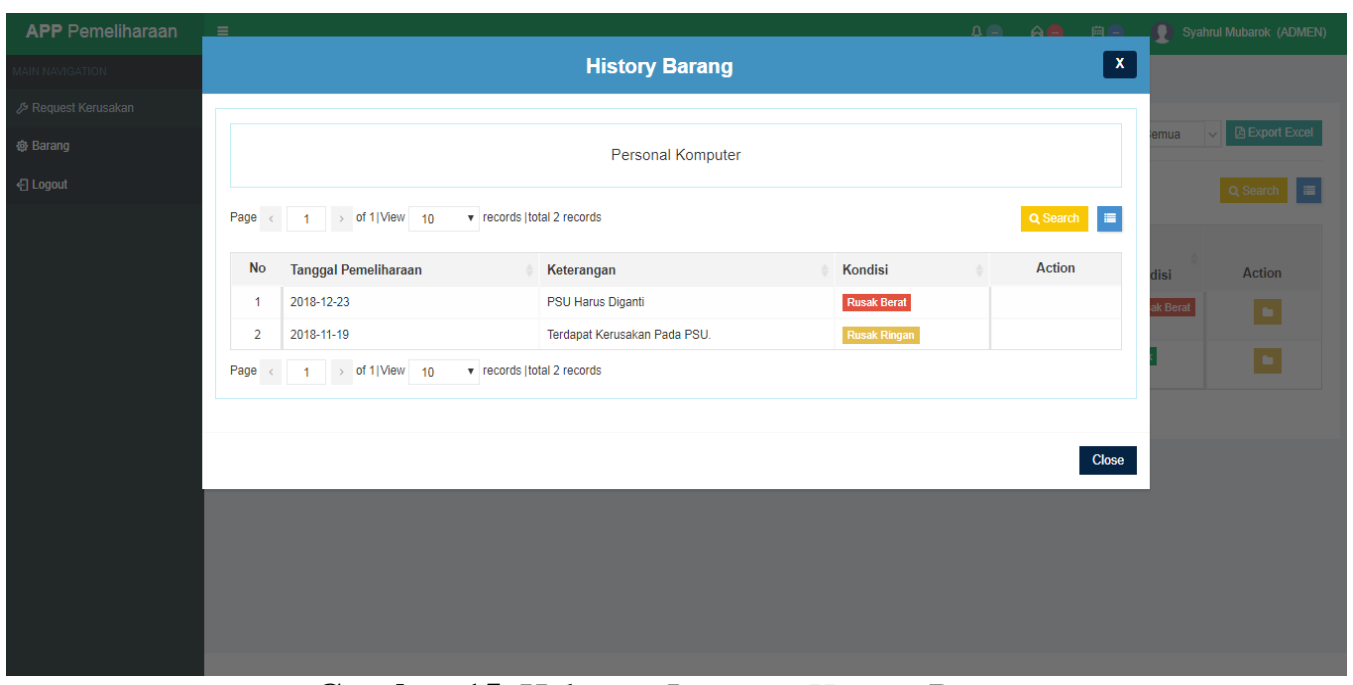

\section{Keterangan :}

Gambar 15. Halaman Laporan History Barang

Untuk melihat tampilan laporan history pemeliharaan barang user cukup pilih menu barang, setelah itu pilih button pada kolom action sehingga muncul history barang keseluruhan. 


\section{Tampilan Laporan Barang}

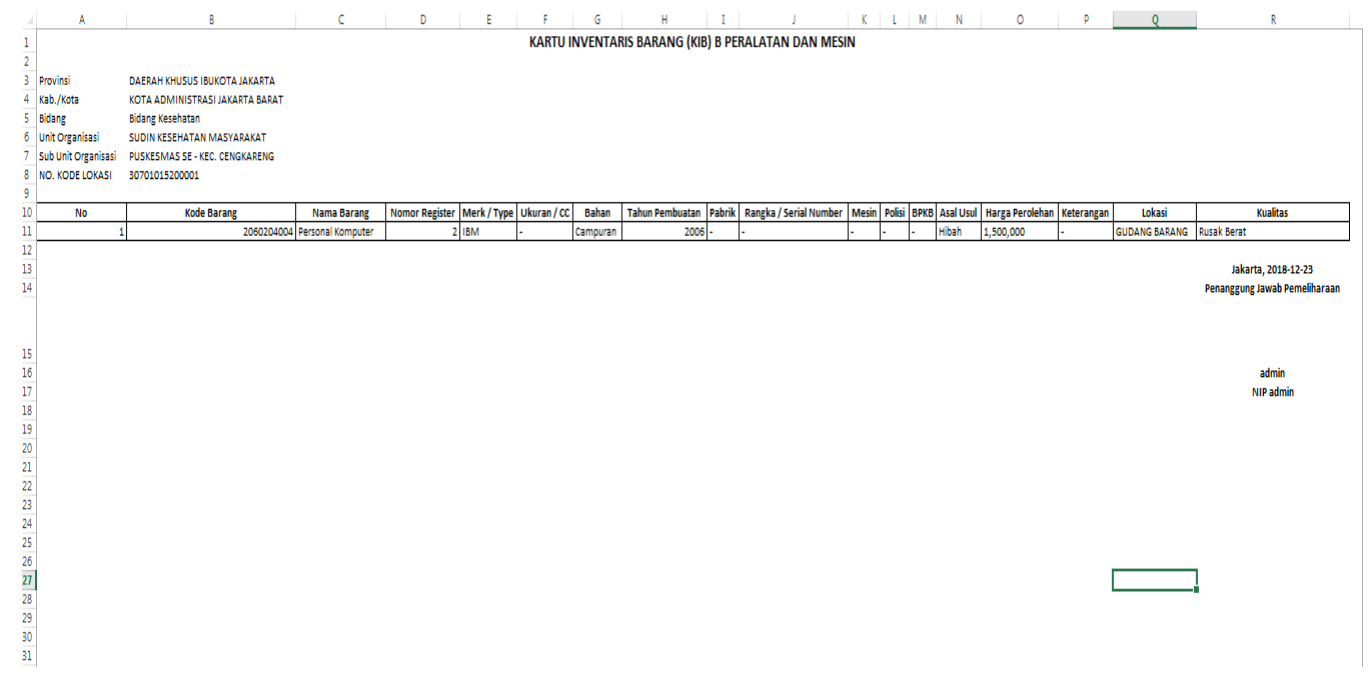

Gambar 16. Halaman Laporan Barang

\section{Keterangan :}

Laporan hasil barang ini dapat diambil dengan cara pilih menu barang lalu user tinggal pilih button export excel dan otomatis akan mengunduh laporan dalam bentuk excel.

\section{TESTING DAN PENGUJIAN}

\section{Pengujian Black Box Testing}

\begin{tabular}{|c|c|c|c|c|c|}
\hline No & $\begin{array}{c}\text { Skenario } \\
\text { Pengujian }\end{array}$ & Test Case & $\begin{array}{l}\text { Hasil Yang } \\
\text { Diharapkan }\end{array}$ & Hasil Pengujian & Kesimpulan \\
\hline 1 & $\begin{array}{l}\text { Login dengan } \\
\text { mengisi } \\
\text { Username dan } \\
\text { Password yang } \\
\text { salah }\end{array}$ & $\begin{array}{l}0 \\
0 \\
0 \\
0 \\
0\end{array}$ & $\begin{array}{l}\text { Sistem akan } \\
\text { menolak akses } \\
\text { dan akan } \\
\text { menampilkan } \\
\text { "Error } \\
\text { Username or } \\
\text { Password } \\
\text { Wrong Failed } \\
\text { Login" }\end{array}$ & $\underbrace{0}_{m=-\infty}$ & Valid \\
\hline 2 & $\begin{array}{l}\text { Login dengan } \\
\text { mengisi } \\
\text { Username dan } \\
\text { Password yang } \\
\text { benar }\end{array}$ & $\begin{array}{l}0 \\
0 \\
0 \\
0\end{array}$ & $\begin{array}{l}\text { Sistem akan } \\
\text { menerima akses } \\
\text { login dan akan } \\
\text { menampilkan } \\
\text { halaman } \\
\text { dashboard } \\
\text { sesuai dengan } \\
\text { tampilan menu } \\
\text { pada hak } \\
\text { aksesnya }\end{array}$ & -5 & Valid \\
\hline
\end{tabular}




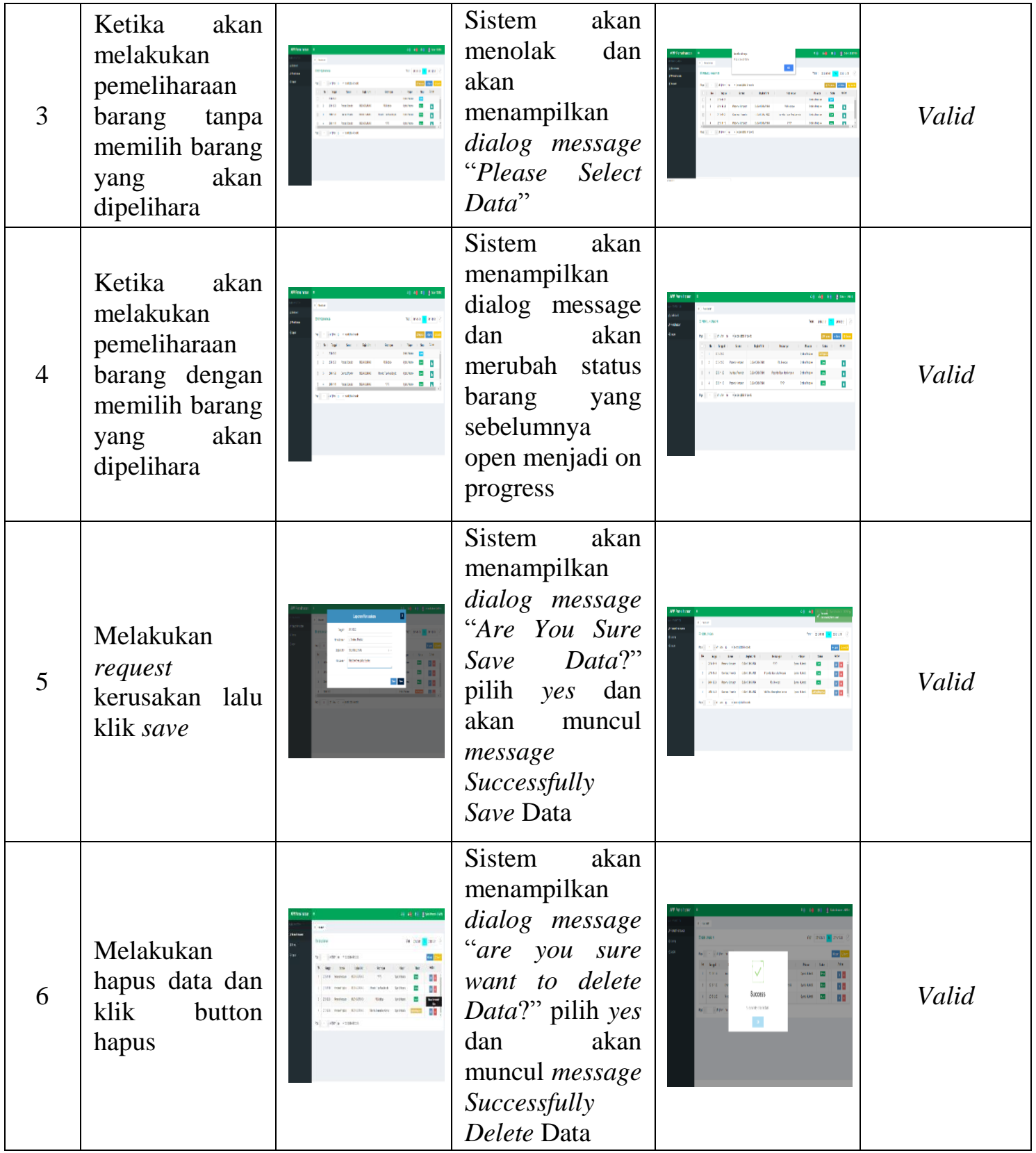

\section{KESIMPULAN}

Berdasarkan analisa yang telah diuraikan pada bab - bab sebelumnya dan juga berdasarkan hasil pengamatan peneliti dari rumusan masalah mengenai Perancangan Sistem Informasi Penunjang Keputusan Rekam Jejak Pemeliharaan Sarana Operasional Berbasis Web Pada BLUD Puskesmas Kecamatan Cengkareng, maka dapat diambil kesimpulan dari rumusan masalahnya sebagai berikut :

1. Sistem pencatatan hasil pemeliharaan pada BLUD Puskesmas Kecamatan Cengkareng masih manual, hal ini belum efektif dan efisien karena data yang dibutuhkan belum terkomputerisasi, sehingga dapat terjadinya kehilangan laporan.

2. Proses pelaporan yang berjalan saat ini masih belum optimal, karena masih menggunakan form yang diisi manual sehingga menimbulkan terselip atau bahkan hilang. 
3. Maka dibutuhkan aplikasi sistem informasi rekam jejak pemeliharaan agar dapat menyimpan semua aktivitas dari mulai pengajuan pemeliharaan, history pemeliharaan suatu barang dan laporan terkini tentang kondisi semua barang.

\section{SARAN}

Dari hasil analisa sistem yang dilakukan peneliti memberi masukan yang diharapkan mampu memberikan perbaikan terhadap sistem yang ada saat ini diantaranya adalah :

1. Untuk kedepannya diharapkan sistem bisa terintegrasi dengan puskesmas tingkat kelurahan.

2. Dalam sistem ini diharapkan ditambahkan menu untuk pencatatan barang yang akan di kalibrasi serta dapat memberikan notifikasi apabila barang yang akan di kalibrasi masa berlaku nya akan habis.

3. Dalam menerapkan sistem informasi rekam jejak pemeliharaan, sebaiknya didukung oleh perangkat yang memadai, baik dari segi sumber daya manusia (brainware) maupun peralatannya (hardware dan software).

\section{DAFTAR PUSTAKA}

[1] Jeperson Hutahaean. 2015. Konsep Sistem Informasi Ed.1 Cet.1. Yogyakarta: Deepublish.

[2] Muslihudin, Muhammad dan Oktafianto. 2016. Analisis dan Perancangan Sistem Informasi Menggunakan Model Terstruktur dan UML Ed.1 Yogyakarta: Andi.

[3] Wijayanti, Aris dan Muhammad Iqbal Baith Firdaus. 2017. Jurnal Inovtek Polbeng Volume 2 No. 1 | ISSN : 2527-9866.

[4] Gulo, Suriaman dan Roni Jhonson Simamora. 2018. Perancangan Sistem Informasi Administrasi Rawat Inap dan Rawat Jalan Pada Rumah Sakit Umum Siti Hajar : METHOMIKA Volume 2 No. 1 | ISSN : 2620-4339.

[5] Sofyan, Abdul Asep, Widia Dewi Astary. 2014. Aplikasi Pengolahan Data Delivery Order di PT. Sinarmas Industries. Jurnal Sisfotek Global Volume 4 No. 1 | ISSN : 2088-1762.

[6] Ariawan, Jesa, Sri Wahyuni. 2015. Aplikasi Pengajuan Lembur Karyawan Berbasis Web. Jurnal Sisfotek Global Volume 5 No. 1 | ISSN : 2088-1762.

[7] Sofiana, Sofa. 2017. Rancang Bangun Dashboard Administrasi Akademik Di SMK Fadilah Tangerang Selatan. Jurnal Informatika Universitas Pamulang Volume 2 No. 1 | ISSN : 2541-1004.

[8] Safitri, Rika Henda, Bunga Aulia. 2017. Optimalisasi Peran Behavioral Accounting Guna Penerapan Dalam Praktik Transfer Pricing. Seminar Nasional Akutansi dan Bisnis | ISSN : 2252-3936.

[9] Sugianto, Akhmad. 2017. Teknik Permainan Balogo dalam Layanan Bimbingan Kelompok Untuk Meningkatkan Karakter Kerja Keras Pada Siswa SMP. Seminar dan Lokakarya Nasional Revitalisasi Laboratorium dan Jurnal Ilmiah Dalam Implementasi Kurikulum Bimbingan dan Konseling. 